\title{
Self-renewal molecular mechanisms of colorectal cancer stem cells
}

\author{
TIANHUI PAN $^{1}$, JINGHONG XU $^{2}$ and YONGLIANG ZHU ${ }^{1}$ \\ ${ }^{1}$ Laboratory of Gastroenterology and ${ }^{2}$ Department of Pathology, The Second Affiliated Hospital of \\ Zhejiang University School of Medicine, Hangzhou, Zhejiang 310009, P.R. China
}

Received October 6, 2015; Accepted November 22, 2016

DOI: $10.3892 /$ ijmm.2016.2815

\begin{abstract}
Colorectal cancer stem cells (CCSCs) represent a small fraction of the colorectal cancer cell population that possess self-renewal and multi-lineage differentiation potential and drive tumorigenicity. Self-renewal is essential for the malignant biological behaviors of colorectal cancer stem cells. While the self-renewal molecular mechanisms of colorectal cancer stem cells are not yet fully understood, the aberrant activation of signaling pathways, such as Wnt, Notch, transforming growth factor- $\beta$ (TGF- $\beta$ )/bone morphogenetic protein (BMP) and Hedgehog-Gli (HH-GLI), specific roles mediated by cell surface markers and micro-environmental factors are involved in the regulation of self-renewal. The elucidation of the molecular mechanisms behind self-renewal may lead to the development of novel targeted interventions for the treatment of colorectal cancer.
\end{abstract}

\section{Contents}

1. Introduction

2. Pathways involved in the self-renewal of CCSCs

3. Molecular surface marker-mediated self-renewal of CCSCs

4. Microenvironment-mediated self-renewal of CCSCs

5. Inflammation factors

\section{Introduction}

Colorectal cancer (CRC) is the second most common type of cancer and the fourth leading cause of cancer-related mortality worldwide, occupying approximately $9.7 \%$ of the total cancer cases and $8.5 \%$ of the number of deaths in 2012 (1). CRC is composed of heterogeneous cell populations differing in gene expression and tumorigenicity $(2,3)$. Sporadic CRC and

Correspondence to: Dr Yongliang Zhu, Laboratory of Gastroenterology, The Second Affiliated Hospital of Zhejiang University School of Medicine, 88 Jiefang Road, Hangzhou, Zhejiang 310009, P.R. China

E-mail: drylzhu@163.com

Key words: colorectal cancer, cancer stem cell, self-renewal, molecular mechanism, signaling pathway, molecular marker, micro-environment hereditary $\mathrm{CRC}$ both originate from the stem cell stage. CRC stem cells (CCSCs) represent a small fraction of the CRC cell population with self-renewal and multi-lineage differentiation potential and the ability to drive tumorigenicity (4).

It is thought that CCSCs originate in three different ways: first, they may be derived from the malignant transformation of normal colorectal stem cells. Colorectal stem cells have the ability to proliferate and self-repair. Gene mutations can further accumulate during their long survival. Evidence has demonstrated that colorectal stem cells become tumorigenic more easily (4-6). Barker et al suggested that only Leucine-rich repeat-containing $\mathrm{G}$ protein-coupled receptor $5(\mathrm{Lgr} 5)^{+}$ stem cells, in cooperation with $A P C$-deficiency, may lead to colorectal adenoma formation (7). The stem-like $\mathrm{Lgr5}^{+}$tumor initiating cells located in the base of adenomas are similar to normal stem cells (8). In the initiation process of CRC, normal colorectal stem cells acquire oncogenic mutations through the interaction between internal and external factors. Subsequently, in the evolution of $\mathrm{CRC}$, the heterozygous loss of $A P C, D C C$ and $p 53$ occurs, accompanied by DNA damage, DNA-repair mutations and altered methylation status $(9,10)$. Second, CCSCs may originate from the dedifferentiation of common cancer cells. Cells with certain differentiation characteristics, such as progenitor cells or mature cells, acquire stemness by dedifferentiation. The successful induction of induced pluripotent stem cells (IPS) has demonstrated that differentiated cells, even in the stage of terminal differentiation, can regain stemness through a reset by certain specific regulation factors. Transducing transcription factor Oct3/4, Sox $2, c-M y c$ and Klf4 into mouse fibroblast cells can drive cells to dedifferentiate and acquire stemness (6). Schwitalla et al indicated that increasing nuclear factor $-\kappa \mathrm{B}(\mathrm{NF}-\kappa \mathrm{B})$ signaling in intestinal epithelial cells would activate the Wnt signaling pathway, thus eliciting dedifferentiation and promoting tumorigenicity (11). Third, CCSCs may originate from cell malignant transformation through the influence of the micro-environment. The transformation of non-cancer stem cells to cancer stem cells is dependent on transforming growth factor- $\beta$ (TGF- $\beta$ ) signaling in the micro-environment, and the process is most likely relevant to epithelial-mesenchymal transition (EMT) $(12,13)$. Mani et al found that mammary gland cells undergoing EMT by Snail or Twist induction regained stem cell markers and the ability to self-renew (14).

CCSCs are heterogeneous, as they contain various subpopulations or are in different stages of stem cell development (2). B-cell-specific Moloney murine leukemia virus insertion 
site $1(\mathrm{Bmi1})^{+}$quiescent cancer stem cells are insensitive to high-doses of radiation, while $\mathrm{Lgr}^{+}$active cancer stem cells have a strong homeostatic regeneration ability (15). If the latter become injured or destroyed, the former can mobilize to transform into an active status. Hence, quiescent cancer stem cells most likely function as a reservoir to maintain the homeostasis of stem cells. The micro-environment dictates the balance between them $(15,16)$. At present, therapy for CRC targets mainly active cells, while quiescent stem cells can escape, leading to relapse and resistance to treatment.

CCSCs are similar to normal adult stem cells as regards biomarkers (Table I). Consequently, three methods have been developed to isolate CCSCs: the first is dependent on cell surface markers. CCSCs can be isolated by FACS based on $\mathrm{CD} 133^{+}(17,18), \mathrm{CD} 44^{+} \mathrm{CD} 24^{+}(19), \mathrm{CD} 44^{+} \mathrm{CD} 58^{+}(20)$ and $\mathrm{CD} 166^{+}(21,22)$. The second is dependent on the characteristic of specific enzymes, such as aldehyde dehydrogenase 1 (ALDH1) (23) and ATP-binding cassette subfamily G member 2 (ABCG2) (24). The third is culturing the cells in serum-free, low-adhesion conditions in vitro and enriching suspending colospheres (25). The methods for identifying CCSC properties include evaluating the ability of continuous sphere formation in vitro, continuous tumorigenicity in NOD/SCID mice and the similarity of differentiation between xenograft tumors and primary tumors.

The characteristics of CCSCs are regulated by different mechanisms. Self-renewal is a fundamental feature of the malignant biological behaviors of CCSCs. Several pathways, cell surface markers and micro-environmental factors are involved in CCSC self-renewal.

\section{Pathways involved in the self-renewal of CCSCs}

The aberrant activation of signaling pathways plays important roles in the evolution and progression of CRC. The Wnt, Notch, bone morphogenetic protein (BMP)/ TGF- $\beta$, Hedgehog-Gli (HH-GLI), epidermal growth factor receptor (EGFR)/mitogen-activated protein kinase (MAPK), $\mathrm{NF}-\kappa \mathrm{B}$ and Akt/mTOR pathways are involved in the selfrenewal of CCSCs (Fig. 1).

Wnt pathway. The Wnt pathway is one of the most important pathways in the tumorigenesis and progression of CRC. Over $90 \%$ of CRC cases display an over-activation of Wnt signaling (26). According to whether this activation is dependent on transcriptional regulation by transporting $\beta$-catenin into the nucleus, the Wnt pathway is divided into the canonical pathway ( $\beta$-catenin-dependent) and the non-canonical pathway ( $\beta$-catenin-independent). The canonical pathway mainly consists of extracellular signaling proteins (Wnt1, Wnt3a, Wnt8, etc.), the transmembrane receptor Frizzled (Fzd), co-receptor low-density lipoprotein-related receptor 5/6 (LRP5/6), Dishevelled (Dsh), $\beta$-catenin, axis inhibitor (Axin) and the intranuclear transcription factor T-cell factor (TCF)/lymphoid enhancer factor (LEF). In the absence of Wnt, $\beta$-catenin interacts with Axin, adenomatous polyposis coli (APC) and glycogen synthase kinase-3 $\beta$ (GSK-3 $\beta$ ) to form a destruction complex and is phosphorylated by GSK-3 $\beta$. Phosphorylated $\beta$-catenin recruits ubiquitin E3 $\beta$-transducin repeat containing protein $(\beta-\mathrm{TrCP})$ and is then degraded by the proteasome, thus maintaining cytoplasmic $\beta$-catenin at a relatively low level (27-29). With Wnt signaling, the Wnt protein binds to the Fzd-LRP complex and recruits Dsh to the cytomembrane. The induction of phosphorylation by Dsh separates GSK-3 $\beta$ from Axin and inhibits the formation of the Axin-GSK-3 $\beta$-APC complex, inhibiting the phosphorylation and ubiquitination of $\beta$-catenin. Free $\beta$-catenin accumulates in the cytoplasm and translocates to the nucleus, targeting LEF and TCF (30). These proteins promote the transcription and expression of downstream targets, such as $c$-Myc, cyclin D1 and Axin2 (31). Disrupting the $\beta$-catenin/TCF-4 activity of $\mathrm{CRC}$ cells induces a rapid G1 arrest and blocks the proliferative compartment in colon crypts from genetic programming. The suppression by $c-M y c$ on the promoter of the cell cycle inhibitor p21 plays an important role in this process. Evidence from conditional gene deletion of $c-M y c$ suggests that $c-M y c(-/-)$ crypt cells are smaller in size and have a slower cycle compared to wild-type cells and $c$-Myc-deficient crypts are prone to loss and can be replaced by $c$-Myc-proficient crypts within weeks $(32,33)$.

In recent years, many other non-classical Wnt proteins have been discovered, establishing a much more complex and precise regulatory network for the canonical Wnt pathway. Yap/ TAZ appears to be an important component of the $\beta$-catenin destruction complex. In the absence of Wnt, YAP/TAZ recruits $\beta$-TrCP to the complex and degrades $\beta$-catenin, blocking pathway activity. When the Wnt pathway is activated, YAP/ TAZ is released from the complex so that $\beta$-catenin can accumulate in the nucleus to stimulate downstream effectors (34). Polycomb group protein Bmi-1 activates Wnt signaling by upregulating the transcription of Wnt factors Wnt3A, Wnt7A, Wnt10A and Wnt4 or by repressing the DKK family. The Wnt downstream target $c-M y c$ in turn promotes the transcription and trans-activation of Bmi-1, forming a positive feedback loop (35). Oncogenic transcription factor MYB cooperates with $\beta$-catenin to co-stimulate $c$-Myc expression (36).

High Wnt activity can define the CCSC population functionally. CRC cells with high Wnt activity upregulate the expression of the stem cell-associated genes, Lgr5 and achaete-scute family bHLH transcription factor 2 (ASCL2), while ones with low Wnt activity upregulate the expression of the epithelial differentiation-associated genes, mucin 2 (MUC2), keratin 20 (KRT20) and fatty acid binding protein 2 (FABP2) (37). CD133+, CD $24^{+} \mathrm{CD} 29^{+}$or $\mathrm{CD} 44^{+} \mathrm{CD} 166^{+}$cells exhibit high Wnt activity (37). High Wnt activity is associated with high clonogenic cancer stem cell potential, while low Wnt activity is not (37). Similar evidence defines the association between Wnt activity and CRC cell proliferation and EMT (38).

Non-canonical Wnt signaling mainly consists of the Wnt/ $\mathrm{Ca}^{2+}$ pathway and JNK-mediated planar cell polarity (PCP) pathway. Under different conditions, non-canonical Wnt pathways function synergistically or antagonistically with the canonical Wnt pathway. The $\mathrm{Wnt} / \mathrm{Ca}^{2+}$ pathway is activated by the interaction between the Wnt-Fzds complex and co-receptor Ror $1 / 2$. They activate phospholipase-C (PLC) to generate 1,2-diacylglycerol (DAG) and inositol 1,4,5-triphosphate (IP3), facilitating the accumulation of $\mathrm{Ca}^{2+}$ in the cytoplasm. The increase in $\mathrm{Ca}^{2+}$ level activates calcinurin $(\mathrm{Cn})$, calmodulin-dependent protein kinase II (CaMKII) and protein 
Table I. The comparison of biomarkers between normal stem cells and CCSCs.

\begin{tabular}{|c|c|c|}
\hline & Marker (Ref.) & Property/function \\
\hline Normal colorectal stem cells & $\begin{array}{l}\text { CD29 (140) } \\
\text { DCAMKL-1 (141) } \\
\text { Lgr5 (106) } \\
\text { Msi-1 (142) } \\
\text { ALDH1 (23) }\end{array}$ & $\begin{array}{l}\text { Cell adhesion molecule } \\
\text { Kinase } \\
\text { Component of the Wnt receptor complex } \\
\text { RNA-binding protein } \\
\text { Detoxifying enzyme }\end{array}$ \\
\hline Colorectal cancer stem cells & $\begin{array}{l}\text { Bmi1 }(143) \\
\text { CD24 }(144) \\
\text { CD29 }(87) \\
\text { CD44 (91) } \\
\text { CD49f }(145) \\
\text { CD58 }(20) \\
\text { CD66c }(146) \\
\text { CD133 }(18) \\
\text { CD166 }(21,22) \\
\text { DCLK1 }(147) \\
\text { EpCAM }(22) \\
\text { Lgr5 }(106) \\
\text { Msi-1 }(142) \\
\text { OLFM4 }(148)\end{array}$ & $\begin{array}{l}\text { A polycomb group protein that regulates gene silencing } \\
\text { Cell adhesion molecule } \\
\text { Cell adhesion molecule } \\
\text { Cell adhesion molecule } \\
\text { Cell adhesion molecule } \\
\text { Cell adhesion molecule } \\
\text { Cell adhesion molecule } \\
\text { Glycoprotein, the most classic marker of CCSCs } \\
\text { Cell adhesion molecule } \\
\text { Kinase } \\
\text { Cell adhesion molecule } \\
\text { Component of the Wnt receptor complex } \\
\text { RNA-binding protein } \\
\text { Glycoprotein }\end{array}$ \\
\hline
\end{tabular}

CCSCs, colorectal cancer stem cells; Lgr5, Leucine-rich repeat-containing G protein-coupled receptor 5; Msi-1, Musashi-1; ALDH1, aldehyde dehydrogenase 1; DCAMKL-1, doublecortin and CaM kinase-like-1; DCLK1, doublecortin-like kinase 1; EpCAM, epithelial cell adhesion molecule; OLFM4, olfactomedin-4.

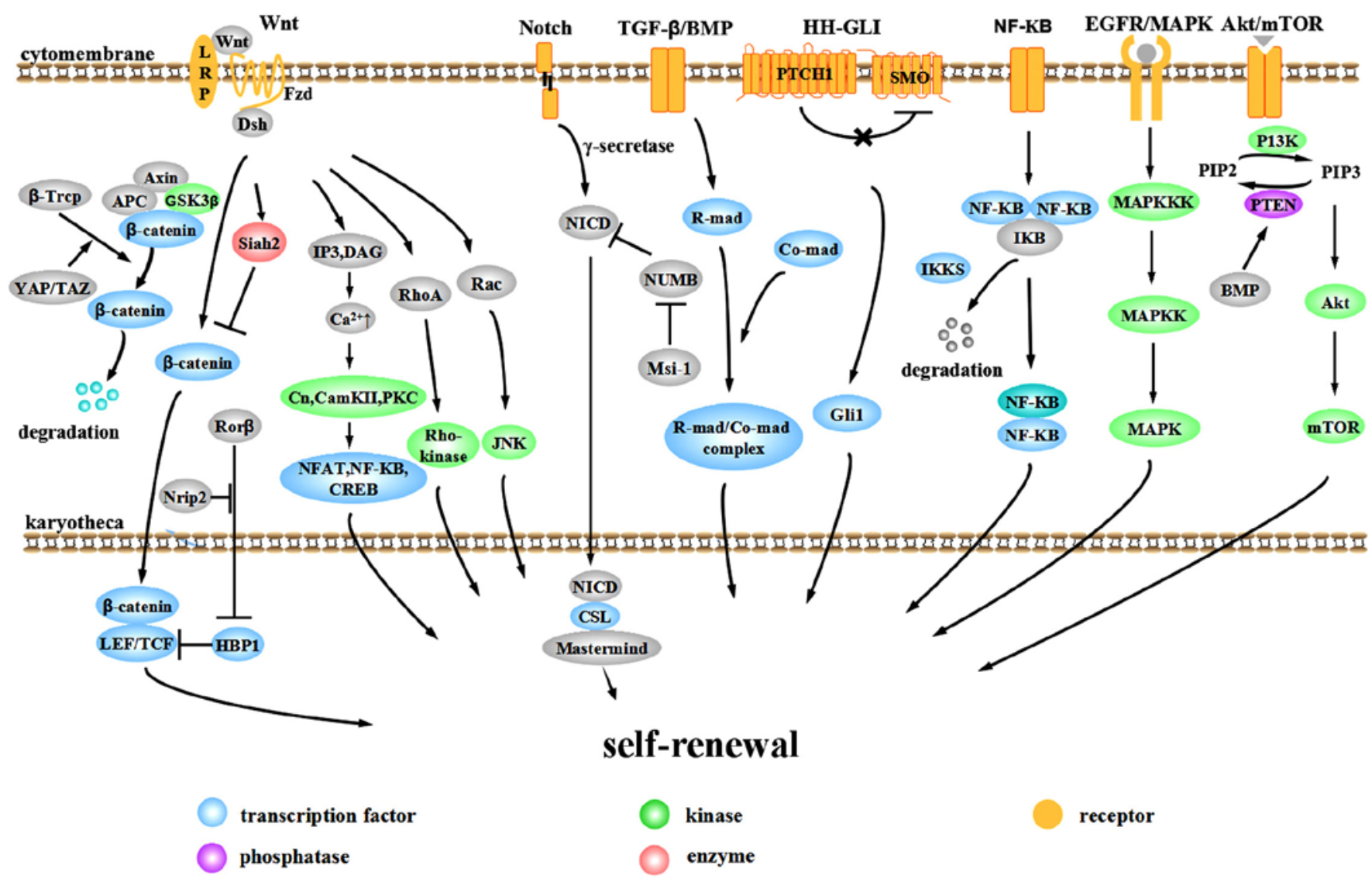

Figure 1. Pathways involved in the self-renewal of colorectal cancer stem cells (CCSCs). 
kinase $\mathrm{C}$ (PKC), which further activate the transcription factor nuclear factor of activated T-cells (NFAT), NF- $\mathrm{BB}$ and cAMP response element binding protein (CREB) (39). In addition, Wnt5/Ror signaling can also generate ubiquitin ligase Siah2, calpain and caudal type homeobox 2 (CDX2). CDX2 acts as a transcription factor to regulate the downstream targets (39). Wnt5a acts differently as a proto-oncogene or tumor suppressor in different tissues. With respect to CRC, MacLeod et al found that Wnt5a can generate Siah2 and promote $\beta$-catenin phosphorylation and degradation, which inhibit the growth of cancer stem cells (40). PKC can phosphorylate $\beta$-catenin independent of GSK-3 $\beta$ to facilitate degradation (41). Moreover, PKC can suppress APC phosphorylation, suggesting that PKC can inhibit colorectal cells from proliferating through the negative regulation of the canonical Wnt pathway by APC (42). The PKC $\alpha$-dependent phosphorylation of retinoic acid-related orphan nuclear receptor $\alpha(\operatorname{ROR} \alpha)$ on serine residue 35 can suppress the expression of target proteins of the canonical Wnt/ $\beta$-catenin pathway (43). CaMKII acts upstream to activate the TAK1-NLK pathway and inhibit the DNA-binding activity of the $\beta$-catenin-TCF- 4 complex through serine/threonine phosphorylation of TCF-4 (44). The Wnt/PCP pathway is mediated by Wnt (Wnt5a, Wnt11)-Fzd and Dsh. Wnt/PCP plays an important role in regulating tissue polarity and cell motility through the activation of small GTP-binding proteins, including Rac and RhoA, and protein kinases, including c-Jun $\mathrm{N}$-terminal kinase (JNK), Rho-associated kinases and nemolike kinase (NLK) (45). Van-Gogh-like 2 is an important component of Wnt/PCP, essential in establishing epithelial cell polarity. Van-Gogh-like 2 inhibits CRC through antagonizing the canonical Wnt pathway (46). By contrast, JNK/c-Jun regulates the expression of TCF4 to promote canonical Wnt signaling (47).

We recently found that nuclear receptor-interacting protein 2 (Nrip2) is a novel interactor of the non-canonical Wnt pathway. Nrip2 inhibits the transcription of HMG-box transcription factor 1 (HBP1) through the arrest of retinoic acid-related orphan nuclear receptor $\beta(\operatorname{ROR} \beta)$ in the cytoplasm and and its subsequent degradation to promote the transcription of the downstream gene, TCF/LEF, a process connected to activating the canonical Wnt signaling pathway (unpublished data).

Notch pathway. Notch can also be divided into canonical and non-canonical pathways. Typical Notch ligands include Delta-like (DLL)1, DLL3, DLL4, jagged (JAG)1 and JAG2 with a Delta-Serrate-Lag 2 (DSL) domain, while atypical ligands include DNER, F3/Contactin and NB-3 without a DSL domain. When the ligand interacts with the Notch1, Notch2, Notch3 or Notch4 receptor, continuous proteolysis is triggered by $\gamma$-secretase, releasing the active Notch intracellular domain (NICD). In the canonical Notch pathway, NICD translocates to the nucleus and binds to the transcription factor, CSL. Then CSL-NICD complex is activated by Mastermind family co-activators for the transcriptional activation of targets HESI and HEYl to suppress differentiation and maintain stemness. Otherwise, NICD binds to nuclear p50 or c-Rel to activate $\mathrm{NF}-\kappa \mathrm{B}$ activity 9 (non-canonical pathway). Another non-canonical Notch pathway is triggered by an atypical Notch ligand to form the CSL-NICD-Deltex complex, activating MAG transcription and promoting differentiation (48).
Which pathway is activated depends on the interaction between ligands and receptors. NUMB regulates intracellular Notch activity in the process of cell division, inhibiting Notch transmission in the cytoplasm (49,50). Musashi-1 (Msi-1), a conservative RNA-binding-protein (RBP), can upregulate Notch activity by inactivating NUMB (51).

In general, an aberrantly activated Notch pathway is oncogenic although anti-oncogenic partly in dermatoma and the cervical uterus (48). Notch activity in the CRC initiating cells is 10- to 30-fold higher than in colon cancer cells. Notch inhibits apoptosis of CCSCs by repressing the cell cycle inhibitor p27. In addition, Notch can maintain self-renewal and inhibit differentiation through repressing secretory cell lineage differentiation targets MUC2 and atonal homolog 1 (ATOH1) (52).

Notch1 and HES1 are involved in the malignant transformation of the normal colonic mucosa (53). HES1 increases stemness-related genes in CRC cells and leads to the overexpression of CCSC markers, such as CD133, ABCG2, Nanog and ALDH1. Additionally, HES1 increases the size of CD133 and stem-like side population cells to enhance selfrenewal properties (54). The inhibition of Notch signaling by a $\gamma$-secretase inhibitor can inhibit the growth of CRC cells, suggesting a potential therapeutic target for CRC (55).

BMP/TGF- $\beta$ pathway. The TGF- $\beta$ family has over 40 members, including the TGF- $\beta$ and BMP subfamily (56). When the signaling is activated, activated receptors further phosphorylate the intracellular receptor-regulated SMAD (R-Smad). Phosphorylated R-Smad interacts with Co-Smad to create a complex that translocates into the nucleus and plays a role as a transcription factor (57).

The downstream targets of TGF- $\beta$ are pivotal cell cycle regulation proteins, including $\mathrm{p} 21, \mathrm{p} 27$ and $\mathrm{p} 15$. In most situations, their activation leads to growth arrest (58). Mutated inactivation occurs in at least one component of almost every CRC case, from frameshift mutations caused by microsatellite instability to mutations of Smad4 and Smad2 (59-62). Zubeldia et al injected colon adenocarcinoma cells pre-treated with TGF- $\beta$ into the spleens of mice and found that it promoted primary tumor development and liver metastasis (63). TGF- $\beta$ can promote EMT through inducing EMT-related transcription factors Snail1/2, Twist and zinc finger E-box binding homeobox (ZEB)1/2 and elicit cell dedifferentiation (64). Snail induces interleukin (IL)-8) expression through binding to its E3/E4 E-boxes, maintaining stemness through function of IL-8. ZEB2 activates the PI3K/AKT pathway and induces cell transformation (65). ZEB2 attenuates the expression of phosphatase and tensin homolog (PTEN) through microRNAs, such as miR-181, miR-200b, miR-25 and miR-92a (66).

As regards the BMP signaling pathway, mutations in the BMP receptor BMPR1A and Smad4 lead to juvenile intestinal polyposis and Cowden disease, respectively (56). The downregulation of BMP3 occurs in $89 \%$ of primary CRC cases. The early silencing and frequent silencing of BMP3 is crucial in CRC progression (67). BMP4 is not expressed in CRC, while it exists in differentiated cells. Recombinant BMP4 promotes the differentiation and apoptosis of CCSCs (68). Inhibiting the BMP pathway with Dorsomorphin causes mesenchymal stem cells to acquire epithelial-like traits, including the expression of cytokeratin-18 and E-cadherin. The progress occurs 
through the downregulation of Snail, Slug and COX2 to affect cell motility, invasiveness and tumor growth in vitro (69). Moreover, in CRC initiation, BMP signaling maintains the balanced control of stem cell self-renewal by inhibiting the Wnt pathway. The zinc-finger transcription factor, GATA binding protein 6 (GATA6) is a crucial regulation factor connecting the Wnt and BMP pathways. Competing with $\beta$-catenin/TCF4, GATA6 binds to a distal regulatory region of BMP4, decreases the threshold of the BMP pathway for CCSC expansion and inhibits stem cell differentiation (70).

HH-GLI pathway. It has been demonstrated that the selfrenewal ability of CCSCs is dependent on HH-GLI activity in vivo (71). HH proteins initiate signaling through binding to transmembrane receptor PATCHED1 (PTCH1) and relieve its inhibition to GPCR-like protein Smoothened (SMO). SMO then localizes to primary cilia and the signaling transduces through several parts to finally mediate the three GLI zinc finger transcription factors, enhancing the GLI1 function and inhibiting GLI repressors. GLI code (the sum of all functions of the three GLI proteins) transforms into an activating state and triggers the expression of target genes such as PTCH1, GLII, HIP, many of which are components of the HH-GLI pathway. Varnat et al found that CRC cells exhibited a high activity of $\mathrm{HH}-\mathrm{GLI}$ signaling and located active $\mathrm{HH}-\mathrm{GLI}$ signaling in $\mathrm{SHH}^{+} / \mathrm{PTCH}^{+} / \mathrm{GLI}^{+}$tumor cells rather than the stroma. They inhibited HH-GLI signaling by RNAi or cyclopamine treatment and tested the influence on CRC cell growth, recurrence and metastases. The results suggested that the growth, recurrence and metastases of CRC xenografts required HH-GLI activity and cells with high $\mathrm{HH}-\mathrm{GLI}$ activity owned stronger EMT potentials. Furthermore, they injected $\mathrm{CD}_{133}{ }^{+}$cells infected with lentivirus encoding $\operatorname{sh} S M O$ or shPTCH1 into nude mice, isolated tumor cells after 2-3 weeks and subsequently analyzed the ratio of $\mathrm{CD} 133^{+}$subpopulation to test stem cell behaviors in vivo. The results suggested that the self-renewal of CCSCs relied on the direct function of HH-GLI activity in vivo (71).

Components of the HH-GLI pathway may also influence CRC progression by connecting to the Wnt pathway. The role is controversial. GLI1 can downregulate the level of $\beta$-catenin, the expression of $c-M y c$ and proliferation ability (72). However, SMO significantly increases in the intestinal adenoma of Apc(+/Delta716) mice and knockdown of SMO in human CRC lines inhibites cell proliferation. In Apc(+/Delta716)SMO(+/-) mice, the number of large polyps decreases, polyp morphology recesses and proliferation of cancer cells reduces. It is further demonstrated the decreased expression of SMO attenuates the $\beta$-catenin-dependent transcription instead of $\mathrm{HH}$-responsive GLI-dependent transcription and SMO promotes tumorigenesis through Wnt signaling (73).

$N F-\kappa B$ pathway. The $\mathrm{NF}-\kappa \mathrm{B}$ pathway regulates immunoinflammatory responses, cell survival and proliferation, playing an important role in tumor formation. Members of the $\mathrm{NF}-\kappa \mathrm{B}$ family often display as dipolymers. In a quiescent condition, $\mathrm{NF}-\kappa \mathrm{B}$ binds to I $\kappa \mathrm{B}$ to form a heteromultimer, residing in the cytoplasm in an inactive state. With the stimulation of $\mathrm{NF}-\kappa \mathrm{B}$ activators, I $\mathrm{B}$ kinase (IKKs) are activated, leading to tripolymer phosphorylation, ubiquitylation of the $\mathrm{N}$-terminus of the I $\kappa \mathrm{B}$ protein and degradation. Thus, the NF- $\kappa \mathrm{B}$ dipolymer is released and is further activated through post-translational modifications. The NF- $\kappa \mathrm{B}$ dipolymer then translocates to the nucleus to interact with $\kappa \mathrm{B}$ sequences and regulates transcription (74).

The CCSC self-renewal mechanisms related to NF- $\kappa \mathrm{B}$ lie mainly in three areas. The first is related to dedifferentiation. Schwitalla et al demonstrated that increasing NF- $\mathrm{NB}$ recruits CREB-binding protein (CBP) and helps CBP to bind RelA/p65 to $\beta$-catenin, thus activating Wnt and inducing the dedifferentiation of non-cancer stem cells (11). The second is the induction of stem cell gene expression. IкB kinase 2 (IKK2ca) is constitutively activated in intestinal epithelial cells and increases stem-like genes ASCL2, olfactomedin 4 (OLFM4), Delta-like 1 homolog $(D L K 1)$ and Bmi-1 in intestinal stem cells to drive intestinal tumorigenesis (75). The third is that IKK2caexpressing intestinal epithelial cells can secrete cytokines and chemokines, induce bone marrow cells, and activate fibroblasts, thus creating a tumor micro-environment (75).

EGFR/MAPK pathway. Epidermal growth factor (EGF) signals are essential for the emergence and maintenance of CCSCs (76). The interaction between EGF and EGFR promotes the dimerization and phosphorylation of receptors, thus activating a downstream signaling cascade involving MAPK, AKT and JAK-STAT (77). The MAPK pathway passes through a three-step phosphorylation to further activate downstream targets (78). EGF promotes the expression of high levels of Musashi-1, Lgr5 and low levels of CK20 by CCSCs, facilitating rapid tumor growth. The activation of EGFR signaling promotes the expression of stem cell-related molecules Notch, Shh, Oct3/4 and Wnt. EGFR inhibitors inhibit CCSC proliferation and induce apoptosis through suppressing EGFR phosphorylation and downstream signaling proteins, such as Akt kinase and ERK kinase (76).

Akt pathway. The Akt cascade regulates cell survival and proliferation in many different tumors (79). Recently, a novel kinase-independent Akt pathway was discovered (80). When the Akt kinase domain is inactivated, Akt can resist a hostile environment through another domain of the Akt protein, which is named PH domain. The process may be related to the regulation of interacting protein partners. The function of $\mathrm{PH}$ domain may be influenced by kinase domain to get to a particular sub-cellular compartment and/or interact with specific effector proteins (80). Akt can be a bridge connecting the BMP pathway with Wnt pathway. BMP positively regulates PTEN activity to inhibit Akt pathway. The active serine/threonine kinase in the Akt pathway can activate 14-3-3zeta in the $\beta$-catenin complex. 14-3-3zeta contributes to the stabilization and nuclear translocation of $\beta$-catenin, thus facilitating CCSC self-renewal by activating Wnt (81).

\section{Molecular surface marker-mediated self-renewal of CCSCs}

CCSC biomarkers are putative to be related to the CCSC phenotype (Table I). Characteristic cellular surface markers, important components of CCSC biomarkers, are what we focus on in this review. Specific mechanisms of these surface markers to regulate CCSC self-renewal are shown in Fig. 2. 


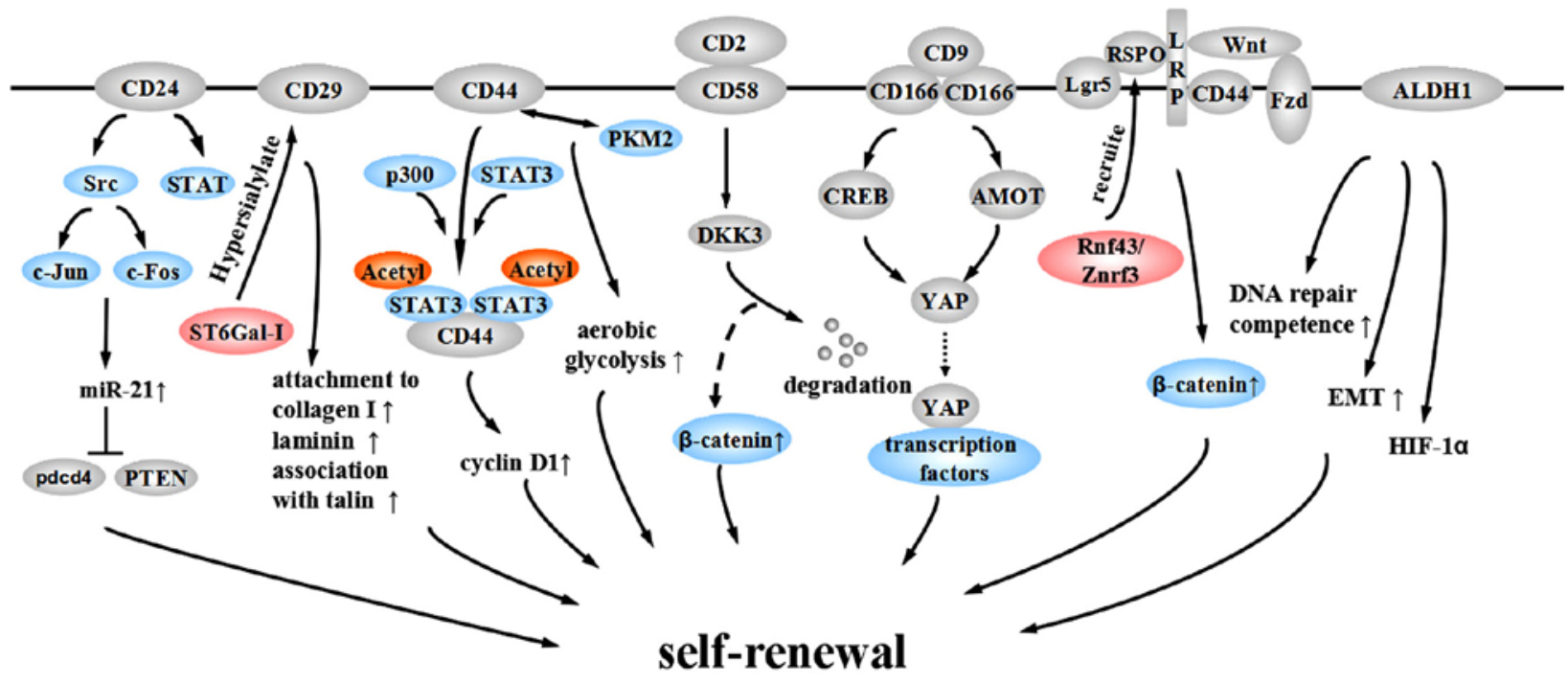

transcription factor

enzyme

acetylation

Figure 2. Molecular surface marker-mediated self-renewal of CCSCs.

CD24. CD24 is a heavily glycosylated protein located on the external membrane surface, promoting the renewal of the cell cycle through increasing proliferation and suppressing apoptosis (82). CD24+ cells exhibit CCSC properties, including high chemotherapy resistance, self-renewal ability and tumorigenic potential (83). The promoter of CD24 contains a $T C F / L E F$ sequence, suggesting that CD24 is a target of the Wnt pathway (84). In addition, CD24 activates the Src pathway and induces the expression of c-Jun and c-Fos to promote the expression of miR-21, which inhibits Pdcd4 and PTEN to facilitate CRC progression (85). Evidence from gastric cancer suggests that CD24 can maintain cell survival and promote invasion through activating STAT (86).

$C D 29$. CD29, also known as $\beta 1$-integrin, heterodimerizes with one of 12 possible $\alpha$ subunits (87). $\beta 1$-integrin is the major integrin protein in normal cells and tumor-associated cells and is thought to play a part in tumor invasion and metastasis. Alteration of expression in integrin $\beta 1$-subunit significantly correlates with lymph node metastasis and depth of invasion in CRC (88). Song et al proposed $\beta 1$-integrin may induce proliferation and migration through HH-GLI pathway (89).

The involvement of $\beta 1$-integrin in tumor invasion depends on the process of hypersialylation. Seales et al discovered oncogenic ras expressed in $50 \%$ of colorectal adenocarcinomas and it upregulated ST6Gal-I, a Golgi glycosyltransferase. The enforced expression of ST6Gal-I in SW48 cells has been shown to induced the sialylation of $\beta 1$-integrin to upregulate attachment to collagen I and laminin and increase the association with talin, a well-accepted marker for integrin activation, which suggests that $\beta 1$-integrin alters cell preference for certain extracellular matrix milieus and stimulates cell migration to promote CRC progression (87).

CD44.CD44 is type I transmembrane glycoprotein, comprised of variable spliceosomes, generating different isoforms through inserting one or more exons into a common framework region.
These variable isoforms may be a critical process in CRC metastasis (90-92). CD44 expression is restricted to the crypt of the epithelia in the normal intestinal mucosa of APC-mutated mice while it is highly expressed in adenomas and invasive carcinomas (93). Although the specificity of CD44 to CCSCs is under debate, CD44 is useful in isolating CCSCs combined with other surface markers $(20,21,94)$. The mechanism of the participation of CD44 in maintaining stemness has mainly three aspects. First, CD44 is a Wnt target gene and is involved in the Wnt-related tumorigenesis. At the level of Wnt receptor LRP6, CD44 phosphorylates LRP6 on Wnt stimulation and assists LRP6 in correct membrane localization (95). Second, internalized CD44 interacts with STAT3 and acetyltransferase p300 to form a complex, eliciting STAT3 acetylation and dimerization. The acetylated STAT3 dimer associated with CD44 translocates to the nucleus dependent on a nuclear localization signal (NLS) and binds to the promoter of cyclin D1, increasing cyclin Dl expression and cell proliferation (96). Further research demonstrates that the $\mathrm{C}$ terminus of the CD44 molecule is related to increased anoikis resistance in sphere-forming cultures while the $\mathrm{N}$ terminus contributes to the interaction with STAT3 and p300. Nuclear CD44/STAT3 signaling promotes the reprogramming of cancer cells, with increasing expression of SOX2 and OCT4. Additionally, CD44 is related to EMT (97). Third, Interaction between CD44 and pyruvate kinase M2 (PKM2) facilitates synthesizing glutathione through the pentose phosphate pathway to resist reactive oxygen species (ROS) accumulation, thus promoting tumor cell aerobic glycolysis to meet the requirements for tumor synthesis demands (98).

CD58. CD58, also known as lymphocyte function-associated antigen-3, is a heavily glycosylated protein on the cell surface and a cell adhesion molecule belonging to the Ig superfamily. CD58 is expressed on the surface of most cells in the hematopoietic system and non-hematopoietic system, including endothelial cells and epithelial cells (20). Colon cancer HT-29 
and Caco-2 cells express CD58 at low levels (99). CD58 is a ligand for CD2 and their interaction functions as a specific immunity co-stimulation to promote $\mathrm{T}$ cells to secrete CXCL-8, which can promote the self-renewal of CCSCs (100). Our research demonstrated that CD58 promotes the maintenance of self-renewal through activating the $\mathrm{Wnt} / \beta$-catenin pathway (20). The DKK family is comprised of inhibitors of the canonical Wnt signaling pathway. CD58 interacts with downstream DKK3 and elicits DKK3 degradation to activate the Wnt pathway (20).

ALCAM/CD166. ALCAM/CD166, belonging to the Ig superfamily, is highly expressed in endogenous intestinal stem cells and is related to intercellular adhesion $(101,102)$. CD166 is a target of the Akt pathway regulated by TGF- $\beta$ and $N F-\kappa B$ p50/p65 (103-105). Whether CD166 is a positive or negative regulator of tumor development is still under debate. Traditional opinions suggest that CD166 is associated with tumor aggression and progression, anti-apoptosis and resistance to autophagy $(101,104)$. CD166 mediates its functions via homophilic (CD166-CD166) or heterophilic (CD166-CD6/9) interactions (102). A recent study indicated that through the PI3K/AKT pathway, CD166 regulates the downstream YAP protein to resist apoptosis, which can be promoted by the interaction between CD9 and CD166. Additionally, the interaction between PI3K/AKT signaling and CD166 can form a positive feedback loop to further promote CD166 expression (105). PI3K/AKT/CD166 regulate the expression and activity of YAP in at least two types of mechanisms. The first utilizes the downstream target CREB to regulate YAP transcription. The second mechanism is the post-transcriptional control of YAP protein stability by suppressing AMOT130 (105).

Lgr5. Lgr5, a G-protein-coupled receptor with a leucine rich repeat, is overexpressed in CRC cells and alters along with CRC progression $(32,106)$. $\mathrm{Lgr}^{+}$cells are located in the crypt base and have the potential to generate all of the intestinal epithelial cell lineages, maintaining self-renewal and homeostasis of the intestinal mucosa $(107,108)$. The mechanism of self-renewal regulation by $\mathrm{Lgr}^{+}$is through the Wnt/ $\beta$-catenin pathway. With activated Wnt signaling, $\mathrm{Lgr}^{+}$ forms a complex with Frizzled/LRP. The complex can bind to Rspondin (RSPO), a Wnt collaborative enhancer, to further enhance Wnt signaling (109). Recently, it has been indicated that after Lgr5 recruits RSPO, RSPO binds to Rnf43/Znrf3, an E3 ligase that ubiquitinates Frizzled to protect Frizzled from degradation and maintain Wnt signaling (110).

$A L D H 1$. ALDH1 is reported to be a potential marker for normal or malignant CCSCs. Immunostaining has demonstrated that normal crypt bases only express a small amount of ALDH1. However, in the transformation from normal epithelia to mutant epithelia, and finally to adenomas, $\mathrm{ALDH}^{+}$cells increase in number and distribute more widerly along the crypt axis (23). Patients with inflammatory bowel diseases with atypical hyperplasia express higher levels of ALDH1, while patients with simple inflammation exhibit no increase. This finding suggests that ALDH1 may be a critical point distinguishing atypical hyperplasia from inflammatory hyperplasia and a potential marker for pre-cancerous lesions (111).
Evidence from prostate cancer suggests that ALDH1A1 activity is associated with increased DNA repair competence and an induction of EMT. ALDH1 A1 $1^{+}$cells express high level of hypoxia inducible factor- $1 \alpha(\mathrm{HIF}-1 \alpha)$. The expression of ALDH1A1 is regulated by the Wnt pathway through $\beta$-catenin/TCF-dependent transcription and co-occurs with the expression of $\beta$-catenin (112).

\section{Microenvironment-mediated self-renewal of CCSCs}

The tumor micro-environment represents non-tumor cells and adjacent tissues, including uncontrollable inflammation. The micro-environment experiences pathological change and provides cancer stem cells with soil, contributing to the complexity of CRC biology. The interaction between CCSCs and the micro-environment plays a role in regulating CCSC self-renewal.

Cancer-associated fibroblasts (CAFs). Fibroblasts in the tumor micro-environment are termed CAFs. This cell population is not stationary, but can be transformed from mesenchymal cells, endothelial cells, adipose cells and even cancer epithelial cells. CAFs promote tumor progression and invasion by both mechanical forces and metabolic machinery (113). On the one hand, CAFs induce protease-mediated extracellular matrix remodeling, serving to guide the structures that direct migration (114). On the other hand, CAFs secrete cytokines and growth factors to affect the proliferation, survival, adhesion and migration of cancer cells. The secreted mitogenic factors involve hepatocyte growth factor, EGF family members, chemokine ligand 12, fibroblast growth factors and stanniocalcin-1 (115). CAFs promote invasion. One of the mechanisms is the secretion of matrix metalloproteases or cytokines, such as tumor necrosis factor- $\alpha$ (TNF- $\alpha$ ) that promotes EMT. Activated CAFs by TGF- $\beta$ can trigger GP130/ STAT3 signaling to express IL-11, contributing to CRC metastasis (116).

$H I F$. Anoxia is recognized to promote tumor survival and progression by inducing changes in tumor metabolism, angiogenesis, invasion, metastasis and drug resistance to reduce the clinical prognosis $(117,118)$. Anoxia regulates gene expression through the transcriptional control of HIF-1 $\alpha$ and HIF- $2 \alpha$, which can bind to hypoxia response elements (HRE) in the promoters of many genes. The induction of these genes triggers aggressive tumor growth, invasion and metastasis $(117,118)$. HIFs are involved in the canonical Wnt pathway. HIF-1 $\alpha$ can increase the transcriptional activity of $\beta$-catenin (119). Moreover, Newton et al found that anoxia could inhibit $A P C$ expression through the suppression of the $H R E$ in the $A P C$ promoter by HIF-1 $\alpha$ (120). Shay et al treated colitis-associated colon cancer with acriflavine, an inhibitor of HIF transcription, and found that it could inhibit the hypoxic induction of M-CSFR and angiogenic factors to inhibit tumor growth and progression (121).

Myeloid-derived suppressor cells (MDSCs). MDSCs are a heterogeneous cell population derived from bone marrow, including immature neutrophils, immature dendritic cells, immature monocytes and early myeloid progenitors (122). The 
recruitment from the circulation to the intestinal mucosa is associated with CXCR2 expression on CRC endothelial cells and immunocytes (123). With stimulation by cytokines from the tumor stroma, such as cyclooxygenase 2 and colony-stimulating factor, MDSCs expand and generate arginase 1, ROS, and inducible nitric oxide synthase to inhibit the anticancer function of NK cells and T cells. This process contributes to the escape from immunological surveillance and promotes tumor initiation and progression (123-125). Additionally, MDSCs can secrete vascular endothelial growth factor A and matrix metalloproteinase (MMP)9 to promote angiogenesis (126). Evidence from ovarian cancer suggests that MDSCs can drive the expression of miRNA101 and subsequently suppress repressor gene $\mathrm{CtBP} 2$. CtBP2 interacts with nuclear genes, leading to increased stemness, tumorigenesis and metastasis in cancer cells (127).

\section{Inflammation factors}

Inflammatory mediators and inflammatory effectors are both important components of the tumor micro-environment. They can be derived from the intrinsic pathway, such as the mutation of an oncogene and chromosomal rearrangement, or the extrinsic pathway, such as infection (128). The two pathways activate transcription factors, mainly NF- $\mathrm{B}$ and STAT3, to elicit the release of downstream inflammatory factors, such as IL-1 $\beta$, IL-6, IL-8, IL-17, IL-23 and TNF- $\alpha(128,129)$. The inflammatory response has a series of tumor facilitating effects, including tumor initiation, survival, malignant transformation, invasion, metastasis, destruction of the adaptive immune response, influencing immune surveillance, and changing chemotherapy resistance $(128,129)$. Activated STAT3 by IL-6 plays an important role in the early stage of colitis-associated CRC. STAT3 upregulates the expression of cell cycle regulators cyclin D1, cyclin D2, cyclin B, protooncogene $m y c$, and anti-apoptotic genes $B c l-2$ and Bcl-2-like 1 to promote proliferation and survival (130). IL-23 can promote CRC cells to generate TGF- $\beta$ and induce the process of EMT to facilitate malignant transformation (131). Activated STAT5 by IL-23 with impaired Socs 3 expression is associated with the metastasis of CRC (132), and the function of the IL-23/IL-17 axis on CRC initiation and progression has been recently recognized (133). IL-17A promotes the malignant progression of CRC through the activation of ERK, p38 MAPK and NF- $\mathrm{BB}$ signaling while it also regulates the production of IL-6 (134). Apart from activating multiple signaling pathways to activate transcription factors, such as STAT3 and $\beta$-catenin to regulate stemness (135), IL-8 is related to EMT. In the induction of EMT by Snail, Snail and IL-8 can form a positive feedback loop and increase the expression of stemness genes Sox2, Nanog and Oct4 (65). Leukotrienes D4 and prostaglandin E2 can increase the $\mathrm{ALDH}^{+}$subpopulation and enhance sphere forming and tumor growth (136). The loss of TGF- $\beta$ can induce the secretion of chemokine CCL9 (CCL15 in humans), which recruits immature myeloid cells that express the CCL9 receptor CCL1. These cells secrete MMP9 and MMP2 to promote CRC invasion and metastasis (137).

The components of the micro-environment are very complex. In addition to the above mentioned, others, such as blood vessels, microorganisms and normal cells, all exert an influence on the micro-environment $(113,138)$. All of these complex components interact with each other to regulate CCSC self-renewal.

Prospectives for CCSC-targeted intervention. Because CCSCs possess a strong resistance to therapy, the clinical effects on CRC are very limited. The reactivation of signaling cascades, enhancement of DNA repair and drug efflux by ABC transportation may be responsible for the resistance (139). Considering that the activation of Wnt is a dominating process in the evolution and progression of CRC (26), the targeted intervention of this pathway should be most reliable. How to block this signaling pathway efficiently and specifically while maintaining normal somatic function is the aim of future study. Additionally, targets on other signaling pathways and micro-environmental factors should be included to achieve the best therapeutic effects.

\section{Acknowledgements}

This study was supported by grants from the Natural Science of Foundation of Zhejiang Province (no. LY14H160023) and the Foundation of Scientific Technology Bureau of Zhejiang Province (no. 2013C33117). The English language editing was performed by Elsevier Webshop.

\section{References}

1. Torre LA, Bray F, Siegel RL, Ferlay J, Lortet-Tieulent J and Jemal A: Global cancer statistics, 2012. CA Cancer J Clin 65: 87-108, 2015.

2. De Sousa E Melo F, Vermeulen L, Fessler E and Medema JP: Cancer heterogeneity - a multifaceted view. EMBO Rep 14: 686-695, 2013.

3. Zeuner A, Todaro M, Stassi G and De Maria R: Colorectal cancer stem cells: From the crypt to the clinic. Cell Stem Cell 15: 692-705, 2014

4. Vaiopoulos AG, Kostakis ID, Koutsilieris Mand Papavassiliou AG: Colorectal cancer stem cells. Stem Cells 30: 363-371, 2012.

5. Pardal R, Clarke MF and Morrison SJ: Applying the principles of stem-cell biology to cancer. Nat Rev Cancer 3: 895-902, 2003.

6. Takahashi K and Yamanaka S: Induction of pluripotent stem cells from mouse embryonic and adult fibroblast cultures by defined factors. Cell 126: 663-676, 2006.

7. Barker N, Ridgway RA, van Es JH, van de Wetering M, Begthel H, van den Born M, Danenberg E, Clarke AR, Sansom OJ and Clevers H: Crypt stem cells as the cells-of-origin of intestinal cancer. Nature 457: 608-611, 2009.

8. Schepers AG, Snippert HJ, Stange DE, van den Born M, van Es JH, van de Wetering $M$ and Clevers $H$ : Lineage tracing reveals $\mathrm{Lgr}^{+}$stem cell activity in mouse intestinal adenomas. Science 337: 730-735, 2012

9. Huang J, Papadopoulos N, McKinley AJ, Farrington SM, Curtis LJ, Wyllie AH, Zheng S, Willson JK, Markowitz SD, Morin P, et al: APC mutations in colorectal tumors with mismatch repair deficiency. Proc Natl Acad Sci USA 93: 9049-9054, 1996.

10. Castets M, Broutier L, Molin Y, Brevet M, Chazot G, Gadot N, Paquet A, Mazelin L, Jarrosson-Wuilleme L, Scoazec JY, et al: DCC constrains tumour progression via its dependence receptor activity. Nature 482: 534-537, 2011.

11. Schwitalla S, Fingerle AA,Cammareri P,Nebelsiek T, Göktuna SI, Ziegler PK, Canli O, Heijmans J, Huels DJ, Moreaux G, et al: Intestinal tumorigenesis initiated by dedifferentiation and acquisition of stem-cell-like properties. Cell 152: 25-38, 2013.

12. Scheel C, Eaton EN, Li SH, Chaffer CL, Reinhardt F, Kah KJ, Bell G, Guo W, Rubin J, Richardson AL, et al: Paracrine and autocrine signals induce and maintain mesenchymal and stem cell states in the breast. Cell 145: 926-940, 2011. 
13. Chaffer CL, Brueckmann I, Scheel C, Kaestli AJ, Wiggins PA, Rodrigues LO, Brooks M, Reinhardt F, Su Y, Polyak K, et al: Normal and neoplastic nonstem cells can spontaneously convert to a stem-like state. Proc Natl Acad Sci USA 108: 7950-7955, 2011

14. Mani SA, Guo W, Liao MJ, Eaton EN, Ayyanan A, Zhou AY, Brooks M, Reinhard F, Zhang CC, Shipitsin M, et al: The epithelial-mesenchymal transition generates cells with properties of stem cells. Cell 133: 704-715, 2008.

15. Yan KS, Chia LA, Li X, Ootani A, Su J, Lee JY, Su N, Luo Y, Heilshorn SC, Amieva MR, et al: The intestinal stem cell markers Bmil and Lgr5 identify two functionally distinct populations. Proc Natl Acad Sci USA 109: 466-471, 2012.

16. Yeung TM, Chia LA, Kosinski CM and Kuo CJ: Regulation of self-renewal and differentiation by the intestinal stem cell niche. Cell Mol Life Sci 68: 2513-2523, 2011.

17. Ricci-Vitiani L, Lombardi DG, Pilozzi E, Biffoni M, Todaro M, Peschle $C$ and De Maria R: Identification and expansion of human colon-cancer-initiating cells. Nature 445: 111-115, 2007.

18. O'Brien CA, Pollett A, Gallinger S and Dick JE: A human colon cancer cell capable of initiating tumour growth in immunodeficient mice. Nature 445: 106-110, 2007.

19. Yeung TM, Gandhi SC, Wilding JL, Muschel R and Bodmer WF Cancer stem cells from colorectal cancer-derived cell lines. Proc Natl Acad Sci USA 107: 3722-3727, 2010

20. Xu S, Wen Z, Jiang Q, Zhu L, Feng S, Zhao Y, Wu J, Dong Q, Mao J and Zhu Y: CD58, a novel surface marker, promotes self-renewal of tumor-initiating cells in colorectal cancer. Oncogene 34: 1520-1531, 2015

21. Horst D, Kriegl L, Engel J, Kirchner T and Jung A: Prognostic significance of the cancer stem cell markers CD133, CD44, and CD166 in colorectal cancer. Cancer Invest 27: 844-850, 2009.

22. Dalerba P, Dylla SJ, Park IK, Liu R, Wang X, Cho RW, Hoey T, Gurney A, Huang EH, Simeone DM, et al: Phenotypic characterization of human colorectal cancer stem cells. Proc Natl Acad Sci USA 104: 10158-10163, 2007.

23. Huang EH, Hynes MJ, Zhang T, Ginestier C, Dontu G, Appelman H, Fields JZ, Wicha MS and Boman BM: Aldehyde dehydrogenase 1 is a marker for normal and malignant human colonic stem cells (SC) and tracks SC overpopulation during colon tumorigenesis. Cancer Res 69: 3382-3389, 2009.

24. Miranda-Lorenzo I, Dorado J, Lonardo E, Alcala S, Serrano AG, Clausell-Tormos J, Cioffi M, Megias D, Zagorac S, Balic A, et al: Intracellular autofluorescence: A biomarker for epithelial cancer stem cells. Nat Methods 11: 1161-1169, 2014.

25. Dotse E and Bian Y: Isolation of colorectal cancer stem-like cells. Cytotechnology 68: 609-619, 2016.

26. Fevr T, Robine S, Louvard D and Huelsken J: Wnt/beta-catenin is essential for intestinal homeostasis and maintenance of intestinal stem cells. Mol Cell Biol 27: 7551-7559, 2007.

27. Gao C, Chen G, Romero G, Moschos S, Xu X and Hu J: Induction of Gsk3 $\beta-\beta$-TrCP interaction is required for late phase stabilization of $\beta$-catenin in canonical Wnt signaling. J Biol Chem 289: 7099-7108, 2014

28. Aberle H, Bauer A, Stappert J, Kispert A and Kemler R beta-catenin is a target for the ubiquitin-proteasome pathway. EMBO J 16: 3797-3804, 1997.

29. Liu C, Li Y, Semenov M, Han C, Baeg GH, Tan Y, Zhang Z, Lin $\mathrm{X}$ and $\mathrm{He} \mathrm{X}$ : Control of beta-catenin phosphorylation/ degradation by a dual-kinase mechanism. Cell 108: 837-847, 2002.

30. Sebio A, Kahn M and Lenz HJ: The potential of targeting Wnt $/ \beta$-catenin in colon cancer. Expert Opin Ther Targets 18 611-615, 2014

31. Krausova $M$ and Korinek V: Wnt signaling in adult intestinal stem cells and cancer. Cell Signal 26: 570-579, 2014.

32. van de Wetering M, Sancho E, Verweij C, de Lau W, Oving I, Hurlstone A, van der Horn K, Batlle E, Coudreuse D, Haramis AP, et al: The beta-catenin/TCF-4 complex imposes a crypt progenitor phenotype on colorectal cancer cells. Cell 111: 241-250, 2002

33. Muncan V, Sansom OJ, Tertoolen L, Phesse TJ, Begthel H, Sancho E, Cole AM, Gregorieff A, de Alboran IM, Clevers H, et al: Rapid loss of intestinal crypts upon conditional deletion of the Wnt/Tcf-4 target gene c-Myc. Mol Cell Biol 26: 8418-8426, 2006.

34. Azzolin L, Panciera T, Soligo S, Enzo E, Bicciato S, Dupont S, Bresolin S, Frasson C, Basso G, Guzzardo V, et al: YAP/TAZ incorporation in the $\beta$-catenin destruction complex orchestrates the Wnt response. Cell 158: 157-170, 2014.
35. Cho JH, Dimri M and Dimri GP: A positive feedback loop regulates the expression of polycomb group protein BMI1 via WNT signaling pathway. J Biol Chem 288: 3406-3418, 2013.

36. Ciznadija D, Tothill R, Waterman ML, Zhao L, Huynh D, Yu RM, Ernst M, Ishii S, Mantamadiotis T, Gonda TJ, et al: Intestinal adenoma formation and MYC activation are regulated by cooperation between MYB and Wnt signaling. Cell Death Differ 16: 1530-1538, 2009

37. Vermeulen L, De Sousa E Melo F, van der Heijden M, Cameron K, de Jong JH, Borovski T, Tuynman JB, Todaro M, Merz $\mathrm{C}$, Rodermond $\mathrm{H}$, et al: Wnt activity defines colon cancer stem cells and is regulated by the microenvironment. Nat Cell Biol 12: 468-476, 2010.

38. Fodde R and Brabletz T: Wnt/beta-catenin signaling in cance stemness and malignant behavior. Curr Opin Cell Biol 19: 150-158, 2007.

39. De A: Wnt $/ \mathrm{Ca}^{2+}$ signaling pathway: A brief overview. Acta Biochim Biophys Sin (Shanghai) 43: 745-756, 2011.

40. MacLeod RJ, Hayes M and Pacheco I: Wnt5a secretion stimulated by the extracellular calcium-sensing receptor inhibits defective Wnt signaling in colon cancer cells. Am J Physiol Gastrointest Liver Physiol 293: G403-G411, 2007.

41. Gwak J, Cho M, Gong SJ, Won J, Kim DE, Kim EY, Lee SS, Kim M, Kim TK, Shin JG, et al: Protein-kinase-C-mediated beta-catenin phosphorylation negatively regulates the Wnt/beta-catenin pathway. J Cell Sci 119: 4702-4709, 2006

42. Hernández-Maqueda JG, Luna-Ulloa LB, Santoyo-Ramos P, Castañeda-Patlán MC and Robles-Flores M: Protein kinase C delta negatively modulates canonical Wnt pathway and cell proliferation in colon tumor cell lines. PLoS One 8: e58540, 2013.

43. Lee JM, Kim IS, Kim H, Lee JS, Kim K, Yim HY, Jeong J, Kim JH, Kim JY, Lee H, et al: RORalpha attenuates Wnt/betacatenin signaling by PKCalpha-dependent phosphorylation in colon cancer. Mol Cell 37: 183-195, 2010.

44. Ishitani T, Kishida S, Hyodo-Miura J, Ueno N, Yasuda J, Waterman M, Shibuya H, Moon RT, Ninomiya-Tsuji J and Matsumoto K: The TAK1-NLK mitogen-activated protein kinase cascade functions in the Wnt-5a/Ca(2+) pathway to antagonize Wnt/beta-catenin signaling. Mol Cell Biol 23: 131-139, 2003.

45. Katoh M: WNT/PCP signaling pathway and human cancer (Review). Oncol Rep 14: 1583-1588, 2005.

46. Piazzi G, Selgrad M, Garcia M, Ceccarelli C, Fini L, Bianchi P, Laghi L, D'Angelo L, Paterini P, Malfertheiner P, et al: Van-Gogh-like 2 antagonises the canonical WNT pathway and is methylated in colorectal cancers. Br J Cancer 108: 1750-1756, 2013.

47. Sancho R, Nateri AS, de Vinuesa AG, Aguilera C, Nye E, Spencer-Dene B and Behrens A: JNK signalling modulates intestinal homeostasis and tumourigenesis in mice. EMBO J 28: 1843-1854, 2009.

48. Katoh $\mathrm{M}$ and Katoh M: Notch signaling in gastrointestinal tract (Review). Int J Oncol 30: 247-251, 2007.

49. Couturier L, Mazouni K and Schweisguth F: Inhibition of Notch recycling by Numb: Relevance and mechanism(s). Cell Cycle 12: 1647-1648, 2013

50. Giebel B and Wodarz A: Notch signaling: Numb makes the difference. Curr Biol 22: R133-R135, 2012.

51. Pastò A, Serafin V, Pilotto G, Lago C, Bellio C, Trusolino L, Bertotti A, Hoey T, Plateroti M, Esposito G, et al: NOTCH3 signaling regulates MUSASHI-1 expression in metastatic colorectal cancer cells. Cancer Res 74: 2106-2118, 2014.

52. Sikandar SS, Pate KT, Anderson S, Dizon D, Edwards RA, Waterman ML and Lipkin SM: NOTCH signaling is required for formation and self-renewal of tumor-initiating cells and for repression of secretory cell differentiation in colon cancer. Cancer Res 70: 1469-1478, 2010

53. Meng RD, Shelton CC, Li YM, Qin LX, Notterman D, Paty PB and Schwartz GK: gamma-Secretase inhibitors abrogate oxaliplatin-induced activation of the Notch-1 signaling pathway in colon cancer cells resulting in enhanced chemosensitivity. Cancer Res 69: 573-582, 2009.

54. Gao F, Zhang Y, Wang S, Liu Y, Zheng L, Yang J, Huang W, Ye Y, Luo W and Xiao D: Hes1 is involved in the self-renewal and tumourigenicity of stem-like cancer cells in colon cancer. Sci Rep 4: 3963, 2014.

55. Ghaleb AM, Aggarwal G, Bialkowska AB, Nandan MO and Yang VW: Notch inhibits expression of the Krüppel-like factor 4 tumor suppressor in the intestinal epithelium. Mol Cancer Res 6: 1920-1927, 2008

56. Mishra L, Derynck R and Mishra B: Transforming growth factor-beta signaling in stem cells and cancer. Science 310: 68-71, 2005. 
57. Kamato D, Burch ML, Piva TJ, Rezaei HB, Rostam MA, Xu S, Zheng W, Little PJ and Osman N: Transforming growth factor- $\beta$ signalling: Role and consequences of Smad linker region phosphorylation. Cell Signal 25: 2017-2024, 2013.

58. Yu M, Trobridge P, Wang Y, Kanngurn S, Morris SM, Knoblaugh $S$ and Grady WM: Inactivation of TGF- $\beta$ signaling and loss of PTEN cooperate to induce colon cancer in vivo. Oncogene 33: 1538-1547, 2014

59. Villanueva A, García C, Paules AB, Vicente M, Megías M, Reyes G, de Villalonga P, Agell N, Lluís F, Bachs O, et al: Disruption of the antiproliferative TGF-beta signaling pathways in human pancreatic cancer cells. Oncogene 17: 1969-1978, 1998

60. Xu X, Brodie SG, Yang X, Im YH, Parks WT, Chen L, Zhou YX, Weinstein M, Kim SJ and Deng CX: Haploid loss of the tumor suppressor Smad4/Dpc4 initiates gastric polyposis and cancer in mice. Oncogene 19: 1868-1874, 2000.

61. Grady WM, Myeroff LL, Swinler SE, Rajput A, Thiagalingam S Lutterbaugh JD, Neumann A, Brattain MG, Chang J, Kim SJ, et al: Mutational inactivation of transforming growth factor beta receptor type II in microsatellite stable colon cancers. Cancer Res 59: 320-324, 1999.

62. Woodford-Richens KL, Rowan AJ, Gorman P, Halford S, Bicknell DC, Wasan HS, Roylance RR, Bodmer WF and Tomlinson IP: SMAD4 mutations in colorectal cancer probably occur before chromosomal instability, but after divergence of the microsatellite instability pathway. Proc Natl Acad Sci USA 98: 9719-9723, 2001

63. Zubeldia IG, Bleau AM, Redrado M, Serrano D, Agliano A, Gil-Puig C, Vidal-Vanaclocha F, Lecanda J and Calvo A: Epithelial to mesenchymal transition and cancer stem cell phenotypes leading to liver metastasis are abrogated by the novel TGF $\beta 1$-targeting peptides P17 and P144. Exp Cell Res 319: 12-22, 2013.

64. Moustakas A and Heldin CH: Signaling networks guiding epithelial-mesenchymal transitions during embryogenesis and cancer progression. Cancer Sci 98: 1512-1520, 2007.

65. Hwang WL1, Yang MH, Tsai ML, Lan HY, Su SH, Chang SC, Teng HW, Yang SH, Lan YT, Chiou SH, et al: SNAIL regulates interleukin-8 expression, stem cell-like activity, and tumorigenicity of human colorectal carcinoma cells. Gastroenterology 141: 279-291, 291, 2011. 10.1053/j.gastro.2011.04.008.

66. Karreth FA, Tay Y, Perna D, Ala U, Tan SM, Rust AG, DeNicola G, Webster KA, Weiss D, Perez-Mancera PA, et al: In vivo identification of tumor- suppressive PTEN ceRNAs in an oncogenic BRAF-induced mouse model of melanoma. Cell 147: 382-395, 2011

67. Loh K, Chia JA, Greco S, Cozzi SJ, Buttenshaw RL, Bond CE, Simms LA, Pike T, Young JP, Jass JR, et al: Bone morphogenic protein 3 inactivation is an early and frequent event in colorectal cancer development. Genes Chromosomes Cancer 47: 449-460, 2008.

68. Lombardo Y, Scopelliti A, Cammareri P, Todaro M, Iovino F, Ricci-Vitiani L, Gulotta G, Dieli F, de Maria R and Stassi G: Bone morphogenetic protein 4 induces differentiation of colorectal cancer stem cells and increases their response to chemotherapy in mice. Gastroenterology 140: 297-309, 2011.

69. Garulli C, Kalogris C, Pietrella L, Bartolacci C, Andreani C, Falconi M, Marchini C and Amici A: Dorsomorphin reverses the mesenchymal phenotype of breast cancer initiating cells by inhibition of bone morphogenetic protein signaling. Cell Signal 26 : 352-362, 2014

70. Whissell G, Montagni E, Martinelli P, Hernando-Momblona X, Sevillano M, Jung P, Cortina C, Calon A, Abuli A, Castells A, et al: The transcription factor GATA6 enables self-renewal of colon adenoma stem cells by repressing BMP gene expression. Nat Cell Biol 16: 695-707, 2014.

71. Varnat F, Duquet A, Malerba M, Zbinden M, Mas C, Gervaz P and Ruiz i Altaba A: Human colon cancer epithelial cells harbour active HEDGEHOG-GLI signalling that is essential for tumour growth, recurrence, metastasis and stem cell survival and expansion. EMBO Mol Med 1: 338-351, 2009.

72. Akiyoshi T, Nakamura M, Koga K, Nakashima H, Yao T, Tsuneyoshi M, Tanaka M and Katano M: Gli1, downregulated in colorectal cancers, inhibits proliferation of colon cancer cells involving Wnt signalling activation. Gut 55: 991-999, 2006.

73. Arimura S, Matsunaga A, Kitamura T, Aoki K, Aoki M and Taketo MM: Reduced level of smoothened suppresses intestinal tumorigenesis by downregulation of Wnt signaling. Gastroenterology 137: 629-638, 2009.

74. Sakamoto K and Maeda S: Targeting NF-kappaB for colorectal cancer. Expert Opin Ther Targets 14: 593-601, 2010.
75. Vlantis K, Wullaert A, Sasaki Y, Schmidt-Supprian M, Rajewsky K, Roskams T and Pasparakis M: Constitutive IKK2 activation in intestinal epithelial cells induces intestinal tumors in mice. J Clin Invest 121: 2781-2793, 2011.

76. Feng Y, Dai X, Li X, Wang H, Liu J, Zhang J, Du Y and Xia L: EGF signalling pathway regulates colon cancer stem cell proliferation and apoptosis. Cell Prolif 45: 413-419, 2012.

77. Al Moustafa AE, Achkhar A and Yasmeen A: EGF-receptor signaling and epithelial-mesenchymal transition in human carcinomas. Front Biosci (Schol Ed) 4: 671-684, 2012.

78. Munshi A and Ramesh R: Mitogen-activated protein kinases and their role in radiation response. Genes Cancer 4: 401-408, 2013.

79. Moschetta M, Reale A, Marasco C, Vacca A and Carratù MR: Therapeutic targeting of the mTOR-signalling pathway in cancer: Benefits and limitations. Br J Pharmacol 171: 3801-3813, 2014.

80. Vivanco I, Chen ZC, Tanos B, Oldrini B, Hsieh WY, Yannuzzi N, Campos C and Mellinghoff IK: A kinase-independent function of AKT promotes cancer cell survival. eLife 3: 3, 2014.

81. Tian Q, He XC, Hood L and Li L: Bridging the BMP and Wnt pathways by PI3 kinase/Akt and 14-3-3zeta. Cell Cycle 4: 215-216, 2005

82. Lim SC: CD24 and human carcinoma: Tumor biological aspects. Biomed Pharmacother 59 (Suppl 2): S351-S354, 2005

83. Ke J, Wu X, Wu X, He X, Lian L, Zou Y, He X, Wang H, Luo Y, Wang L, et al: A subpopulation of $\mathrm{CD} 24^{+}$cells in colon cancer cell lines possess stem cell characteristics. Neoplasma 59: 282-288, 2012

84. Shulewitz M, Soloviev I, Wu T, Koeppen H, Polakis P and Sakanaka C: Repressor roles for TCF-4 and Sfrp1 in Wnt signaling in breast cancer. Oncogene 25: 4361-4369, 2006.

85. Muppala S, Mudduluru G, Leupold JH, Buergy D, Sleeman JP and Allgayer $\mathrm{H}: \mathrm{CD} 24$ induces expression of the oncomir miR-21 via Src, and CD24 and Src are both post-transcriptionally downregulated by the tumor suppressor miR-34a. PLoS One 8 e59563, 2013

86. Wang YC, Wang JL, Kong X, Sun TT, Chen HY, Hong J and Fang JY: CD24 mediates gastric carcinogenesis and promotes gastric cancer progression via STAT3 activation. Apoptosis 19 643-656, 2014

87. Seales EC, Jurado GA, Brunson BA, Wakefield JK, Frost AR and Bellis SL: Hypersialylation of betal integrins, observed in colon adenocarcinoma, may contribute to cancer progression by upregulating cell motility. Cancer Res 65: 4645-4652, 2005.

88. Fujita S, Watanabe M, Kubota T, Teramoto T and Kitajima M Alteration of expression in integrin beta 1-subunit correlates with invasion and metastasis in colorectal cancer. Cancer Lett 91: 145-149, 1995.

89. Song J, Zhang J, Wang J, Wang J, Guo X and Dong W: $\beta 1$ integrin mediates colorectal cancer cell proliferation and migration through regulation of the Hedgehog pathway. Tumour Biol 36: 2013-2021, 2015.

90. Marhaba R and Zöller M: CD44 in cancer progression: Adhesion, migration and growth regulation. J Mol Histol 35 211-231, 2004

91. Du L, Wang H, He L, Zhang J, Ni B, Wang X, Jin H, Cahuzac N, Mehrpour M, Lu Y, et al: CD44 is of functional importance for colorectal cancer stem cells. Clin Cancer Res 14: 6751-6760, 2008.

92. Bánky B, Rásó-Barnett L, Barbai T, Tímár J, Becságh P and Rásó E: Characteristics of CD44 alternative splice pattern in the course of human colorectal adenocarcinoma progression. Mol Cancer 11: 83, 2012

93. Wielenga VJ, Smits R, Korinek V, Smit L, Kielman M, Fodde R, Clevers $\mathrm{H}$ and Pals ST: Expression of CD44 in Apc and Tcf mutant mice implies regulation by the WNT pathway. Am J Pathol 154: 515-523, 1999

94. Wang C, Xie J, Guo J, Manning HC, Gore JC and Guo N: Evaluation of CD44 and CD133 as cancer stem cell markers for colorectal cancer. Oncol Rep 28: 1301-1308, 2012.

95. Schmitt M, Metzger M, Gradl D, Davidson G and OrianRousseau V: CD44 functions in Wnt signaling by regulating LRP6 localization and activation. Cell Death Differ 22: 677-689, 2015.

96. Lee JL, Wang MJ and Chen JY: Acetylation and activation of STAT3 mediated by nuclear translocation of CD44. J Cell Biol 185: 949-957, 2009.

97. Su YJ, Lai HM, Chang YW, Chen GY and Lee JL: Direct reprogramming of stem cell properties in colon cancer cells by CD 44 EMBO J 30: 3186-3199, 2011 
98. Tamada M, Nagano O, Tateyama S, Ohmura M, Yae T, Ishimoto T, Sugihara E, Onishi N, Yamamoto T, Yanagawa H, et al: Modulation of glucose metabolism by CD44 contributes to antioxidant status and drug resistance in cancer cells. Cancer Res 72: 1438-1448, 2012.

99. Kvale D, Krajci P and Brandtzaeg P: Expression and regulation of adhesion molecules ICAM-1 (CD54) and LFA-3 (CD58) in human intestinal epithelial cell lines. Scand J Immunol 35: 669-676, 1992.

100. Ebert EC, Panja A and Praveen R: Human intestinal intraepithelial lymphocytes and epithelial cells coinduce interleukin- 8 production through the CD2-CD58 interaction. Am J Physiol Gastrointest Liver Physiol 296: G671-G677, 2009.

101.Levin TG, Powell AE, Davies PS, Silk AD, Dismuke AD, Anderson EC, Swain JR and Wong MH: Characterization of the intestinal cancer stem cell marker CD166 in the human and mouse gastrointestinal tract. Gastroenterology 139: 2072-2082.e5, 2010.

102. Gilsanz A, Sánchez-Martín L, Gutiérrez-López MD, Ovalle S, Machado-Pineda Y, Reyes R, Swart GW, Figdor CG, Lafuente EM and Cabañas C: ALCAM/CD166 adhesive function is regulated by the tetraspanin CD9. Cell Mol Life Sci 70: 475-493, 2013.

103. Hansen AG, Arnold SA, Jiang M, Palmer TD, Ketova T, Merkel A, Pickup M, Samaras S, Shyr Y, Moses HL, et al: ALCAM/CD166 is a TGF- $\beta$-responsive marker and functional regulator of prostate cancer metastasis to bone. Cancer Res 74: 1404-1415, 2014.

104. Wang J, Gu Z, Ni P, Qiao Y, Chen C, Liu X, Lin J, Chen N and Fan Q: NF-kappaB P50/P65 hetero-dimer mediates differential regulation of CD166/ALCAM expression via interaction with micoRNA-9 after serum deprivation, providing evidence for a novel negative auto-regulatory loop. Nucleic Acids Res 39: 6440-6455, 2011.

105. Ma L, Wang J, Lin J, Pan Q, Yu Y and Sun F: Cluster of differentiation 166 (CD166) regulated by phosphatidylinositide 3-Kinase (PI3K)/AKT signaling to exert its anti-apoptotic role via yes-associated protein (YAP) in liver cancer. J Biol Chem 289: 6921-6933, 2014

106. Barker N, van Es JH, Kuipers J, Kujala P, van den Born M, Cozijnsen M, Haegebarth A, Korving J, Begthel H, Peters PJ, et al: Identification of stem cells in small intestine and colon by marker gene Lgr5. Nature 449: 1003-1007, 2007.

107. Ritsma L, Ellenbroek SI, Zomer A, Snippert HJ, de Sauvage FJ, Simons BD, Clevers $\mathrm{H}$ and van Rheenen J: Intestinal crypt homeostasis revealed at single-stem-cell level by in vivo live imaging. Nature 507: 362-365, 2014

108. Gerbe F, van Es JH, Makrini L, Brulin B, Mellitzer G, Robine S Romagnolo B, Shroyer NF, Bourgaux JF, Pignodel C, et al: Distinct ATOH1 and Neurog3 requirements define tuft cells as a new secretory cell type in the intestinal epithelium. J Cell Biol 192: 767-780, 2011.

109. Schuijers J and Clevers H: Adult mammalian stem cells: The role of Wnt, Lgr5 and R-spondins. EMBO J 31: 2685-2696, 2012

110. de Lau W, Peng WC, Gros P and Clevers H: The R-spondin/Lgr5/ Rnf43 module: Regulator of Wnt signal strength. Genes Dev 28: 305-316, 2014

111. Toll AD, Boman BM and Palazzo JP: Dysplastic lesions in inflammatory bowel disease show increased positivity for the stem cell marker aldehyde dehydrogenase. Hum Pathol 43: 238-242, 2012.

112. Cojoc M, Peitzsch C, Kurth I, Trautmann F, Kunz-Schughart LA Telegeev GD, Stakhovsky EA, Walker JR, Simin K, Lyle S, et al: Aldehyde dehydrogenase is regulated by Beta-catenin/TCF and promotes radioresistance in prostate cancer progenitor cells. Cancer Res 75: 1482-1494, 2015.

113. Chen S and Huang EH: The colon cancer stem cell microenvironment holds keys to future cancer therapy. J Gastrointest Surg 18: 1040-1048, 2014

114. Cirri P and Chiarugi P: Cancer-associated-fibroblasts and tumour cells: A diabolic liaison driving cancer progression. Cancer Metastasis Rev 31: 195-208, 2012.

115. Calon A, Tauriello DV and Batlle E: TGF-beta in CAF-mediated tumor growth and metastasis. Semin Cancer Biol 25: 15-22, 2014

116. Calon A, Espinet E, Palomo-Ponce S, Tauriello DV, Iglesias M Céspedes MV, Sevillano M, Nadal C, Jung P, Zhang XH, et al: Dependency of colorectal cancer on a TGF- $\beta$-driven program in stromal cells for metastasis initiation. Cancer Cell 22: 571-584, 2012.

117. McIntyre A and Harris AL: Metabolic and hypoxic adaptation to anti-angiogenic therapy: A target for induced essentiality. EMBO Mol Med 7: 368-379, 2015.
118. Rebucci M and Michiels C: Molecular aspects of cancer cell resistance to chemotherapy. Biochem Pharmacol 85: 1219-1226, 2013.

119. Santoyo-Ramos P, Likhatcheva M, García-Zepeda EA, Castañeda-Patlán MC and Robles-Flores M: Hypoxia-inducible factors modulate the stemness and malignancy of colon cancer cells by playing opposite roles in canonical Wnt signaling. PLoS One 9: e112580, 2014.

120. Newton IP, Kenneth NS, Appleton PL, Näthke I and Rocha S: Adenomatous polyposis coli and hypoxia-inducible factor-1\{alpha\} have an antagonistic connection. Mol Biol Cell 21: 3630-3638, 2010.

121. Shay JE, Imtiyaz HZ, Sivanand S, Durham AC, Skuli N, Hsu S, Mucaj V,Eisinger-Mathason TS, Krock BL, Giannoukos DN, et al: Inhibition of hypoxia-inducible factors limits tumor progression in a mouse model of colorectal cancer. Carcinogenesis 35: 1067-1077, 2014

122. Gabrilovich DI, Ostrand-Rosenberg S and Bronte V: Coordinated regulation of myeloid cells by tumours. Nat Rev Immunol 12: 253-268, 2012.

123. Katoh H, Wang D, Daikoku T, Sun H, Dey SK and Dubois RN: CXCR2-expressing myeloid-derived suppressor cells are essential to promote colitis-associated tumorigenesis. Cancer Cell 24: 631-644, 2013.

124. Gabrilovich DI and Nagaraj S: Myeloid-derived suppressor cells as regulators of the immune system. Nat Rev Immunol 9: $162-174,2009$

125. Murdoch C, Muthana M, Coffelt SB and Lewis CE: The role of myeloid cells in the promotion of tumour angiogenesis. Nat Rev Cancer 8: 618-631, 2008.

126. Motz GT and Coukos G: The parallel lives of angiogenesis and immunosuppression: Cancer and other tales. Nat Rev Immunol 11: 702-711, 2011.

127. Cui TX, Kryczek I, Zhao L, Zhao E, Kuick R, Roh MH, Vatan L, Szeliga W, Mao Y, Thomas DG, et al: Myeloid-derived suppressor cells enhance stemness of cancer cells by inducing microRNA101 and suppressing the corepressor CtBP2. Immunity 39: 611-621, 2013.

128. Mantovani A, Allavena P, Sica A and Balkwill F: Cancer-related inflammation. Nature 454: 436-444, 2008.

129. Grivennikov SI, Greten FR and Karin M: Immunity, inflammation, and cancer. Cell 140: 883-899, 2010.

130. Elinav E, Nowarski R, Thaiss CA, Hu B, Jin C and Flavell RA Inflammation-induced cancer: Crosstalk between tumours, immune cells and microorganisms. Nat Rev Cancer 13: 759-771, 2013.

131. Suzuki H, Ogawa H, Miura K, Haneda S, Watanabe K, Ohnuma S, Sasaki H, Sase T, Kimura S, Kajiwara T, et al: IL-23 directly enhances the proliferative and invasive activities of colorectal carcinoma. Oncol Lett 4: 199-204, 2012.

132. Zhang L, Li J, Li L, Zhang J, Wang X, Yang C, Li Y, Lan F and Lin P: IL-23 selectively promotes the metastasis of colorectal carcinoma cells with impaired Socs 3 expression via the STAT5 pathway. Carcinogenesis 35: 1330-1340, 2014.

133. Grivennikov SI, Wang K, Mucida D, Stewart CA, Schnabl B, Jauch D, Taniguchi K, Yu GY, Osterreicher CH, Hung KE, et al: Adenoma-linked barrier defects and microbial products drive IL-23/IL-17-mediated tumour growth. Nature 491: 254-258, 2012.

134. Wang K, Kim MK, Di Caro G, Wong J, Shalapour S, Wan J, Zhang W, Zhong Z, Sanchez-Lopez E, Wu LW, et al: Interleukin-17 receptor a signaling in transformed enterocytes promotes early colorectal tumorigenesis. Immunity 41: 1052-1063, 2014.

135. Waugh DJ and Wilson C: The interleukin-8 pathway in cancer. Clin Cancer Res 14: 6735-6741, 2008.

136. Bellamkonda K, Sime W and Sjolander A: The impact of inflammatory lipid mediators on colon cancer-initiating cells. Mol Carcinog 54: 1315-1327, 2014.

137. Taketo MM: Roles of stromal microenvironment in colon cancer progression. J Biochem 151: 477-481, 2012.

138. Sun J: Enteric bacteria and cancer stem cells. Cancers (Basel) 3 285-297, 2010

139. Ischenko I, Seeliger H, Schaffer M, Jauch KW and Bruns CJ: Cancer stem cells: How can we target them? Curr Med Chem 15: 3171-3184, 2008.

140. Fujimoto K, Beauchamp RD and Whitehead RH: Identification and isolation of candidate human colonic clonogenic cells based on cell surface integrin expression. Gastroenterology 123: 1941-1948, 2002. 
141. May R, Riehl TE, Hunt C, Sureban SM, Anant S and Houchen CW: Identification of a novel putative gastrointestinal stem cell and adenoma stem cell marker, doublecortin and $\mathrm{CaM}$ kinase-like-1, following radiation injury and in adenomatous polyposis coli/multiple intestinal neoplasia mice. Stem Cells 26 : 630-637, 2008.

142.Li D, Peng X, Yan D, Tang H, Huang F, Yang Y and Peng Z: Msi-1 is a predictor of survival and a novel therapeutic target in colon cancer. Ann Surg Oncol 18: 2074-2083, 2011.

143. Yu T, Chen X, Zhang W, Colon D, Shi J, Napier D, Rychahou P, Lu W, Lee EY, Weiss HL, et al: Regulation of the potential marker for intestinal cells, Bmil, by $\beta$-catenin and the zinc finger protein KLF4: Implications for colon cancer. J Biol Chem 287: 3760-3768, 2012.

144. Sagiv E, Memeo L, Karin A, Kazanov D, Jacob-Hirsch J, Mansukhani M, Rechavi G, Hibshoosh H and Arber N: CD24 is a new oncogene, early at the multistep process of colorectal cancer carcinogenesis. Gastroenterology 131: 630-639, 2006.
145.Haraguchi N, Ishii H, Mimori K, Ohta K, Uemura M, Nishimura J, Hata T, Takemasa I, Mizushima T, Yamamoto H, et al: CD49f-positive cell population efficiently enriches colon cancer-initiating cells. Int J Oncol 43: 425-430, 2013.

146. Gemei M, Mirabelli P, Di Noto R, Corbo C, Iaccarino A, Zamboli A, Troncone G, Galizia G, Lieto E, Del Vecchio L, et al: CD66c is a novel marker for colorectal cancer stem cell isolation, and its silencing halts tumor growth in vivo. Cancer 119: 729-738, 2013.

147. Nakanishi Y, Seno H, Fukuoka A, Ueo T, Yamaga Y, Maruno T, Nakanishi N, Kanda K, Komekado H, Kawada M, et al: Dclk1 distinguishes between tumor and normal stem cells in the intestine. Nat Genet 45: 98-103, 2013.

148. van der Flier LG, Haegebarth A, Stange DE, van de Wetering M and Clevers H: OLFM4 is a robust marker for stem cells in human intestine and marks a subset of colorectal cancer cells. Gastroenterology 137: 15-17, 2009. 